\title{
Aerated lagooning of agro-industrial wastewater: depuration performance and energy requirements
}

\section{Serafina Andiloro, Giuseppe Bombino, Vincenzo Tamburino, Demetrio Antonio Zema, Santo Marcello Zimbone}

\author{
Department "AGRARIA", “Mediterranea" University of Reggio Calabria, loc. Feo di Vito, \\ Reggio Calabria, Italy
}

\begin{abstract}
Intensive depuration plants have often shown low reliability and economic sustainability, when utilised for agro-industrial wastewater treatment, due to the particular wastewater properties: high organic load and essential oil concentrations, acidity, nutrient scarcity and qualitative-quantitative variability of effluents. Aerated lagooning systems represent a suitable alternative, because they are able to assure good reliability and low energy requirements, avoiding the drawbacks shown by the intensive depuration plants. In order to optimize performance of the lagooning systems, particularly in terms of energy requirements, depuration processes of aerobic-anaerobic aerated lagoons were investigated, both at full- and laboratory-scale. Citrus processing wastewater were subject to bubble aeration with low flow rates and limited time; the removal rate of organic load was evaluated and energy requirements of different depuration schemes were compared. The experimental investigations in full-scale aerated lagoons showed a low energy supply (0.21-0.59 kWh per kg of COD (Chemical Oxygen Demand) removed with an average value of $0.45 \mathrm{kWh} \mathrm{kg}_{\mathrm{COD}^{-1}}{ }^{-1}$ ), an adequate equalisation capability and constantly good depurative performance also with high concentrations of essential oil (500-1000 ppm). The experimental investigations in lab-scale aerated tanks
\end{abstract}

Correspondence: Demetrio Antonio Zema, Department "Agraroa", "Mediterranea" University of Reggio Calabria, loc. Feo di Vito, I-89124 Reggio Calabria, Italy.

E-mail: dzema@unirc.it

Key words: aerated lagoon, agro-industrial wastewater, depuration, energy requirement, essential oil, Chemical 0xygen Demand.

Acknowledgements: this work was supported by the research project "PRIN 2008 - Depuration and Reuse of Citrus Processing Wastewater" (Scientific responsibility: Vincenzo Tamburino).

Contributions: the contributions of the authors to this work can be considered equivalent.

(C) Copyright S. Andiloro et al., 2013

Licensee PAGEPress, Italy

Journal of Agricultural Engineering 2013; XLIV(s2):e166

doi:10.4081/jae.2013.s2.e166

This article is distributed under the terms of the Creative Commons Attribution Noncommercial License (by-nc 3.0) which permits any noncom- under controlled conditions indicated the possibility of decreasing energy requirements (down to $0.16 \mathrm{kWh} \mathrm{kg}_{\mathrm{COD}^{-1}}{ }^{-1}$ ) by reducing aeration power (down to $0.6 \mathrm{~W} \mathrm{~m}^{-3}$ ) and limiting aeration time to night 12 hours only, when energy price is lower. In spite of the low aeration, the COD removal rates were on the average six-fold higher compared to the anaerobic tank. Other outcomes indicated an ability of the spontaneous microflora to adapt to high concentrations of essential oils, which however did not provide an increase of the removal rate of the organic load in the experimented scheme.

\section{Introduction}

Depuration of citrus processing wastewater (water from washing fruits machinery, and floors as well as from the extraction of juice and essential oils, peel drying and cooling, Kimball, 1999) poses heavy environmental and economic difficulties, because of high essential oil (E0) content, high oxygen demand and energy requirement, high acidity, lack of nutrients and qualitative and quantitative variability.

Citrus processing wastewater, like other agro-industrial effluents, have been often depurated in intensive biological plants, mainly by activated sludge, often designed by the same criteria used for urban wastewater depuration, which neglect peculiar citrus wastewater characteristics. These intensive depuration processes have often shown low reliability and high energy costs. In order to overcome the drawbacks of the intensive plants and lower the energy requirements, aerated lagooning systems have been proposed for such kind of wastewater with positive results (Tamburino et al., 2007; Van Dyke et al., 2003).

In aerated lagoons, wastewater is usually stored in large and deep basins with long retention time (Jail et al., 2010). The most common lagoons are aerobic-anaerobic with low-intensity aeration (less than $2.5 \mathrm{~W} \mathrm{~m}^{-3}$ ) determining low concentrations of dissolved oxygen (D0) and suspended solids; the sludge settles at the bottom where it is subject to anaerobic digestion. Biological processes in aerated lagoons do not require the constant settleability of sludge large flocs, as required by activated sludge plants; in these plants sludge settlement is a crucial phase which is negatively affected by E0 concentrations over 50 $\mathrm{ppm}$, high COD/N/P ratios and low D0 concentrations (Tamburino et al., 2007; Bombino et al., 2009)

In order to enhance reduction of energy requirements, the management operations of aerated lagooning systems should be further investigated. To this aim, in this paper depuration processes of citrus processing wastewater were investigated at full scale (in an aerobicanaerobic aerated lagoon) and at laboratory scale (in aerated tanks simulating the aerobic surface layer of an aerated lagoon under controlled environmental conditions), in order to evaluate the performances and energy efficiency of lagooning systems with different aeration rates and times as well as EO oil concentrations. 


\section{Materials and methods}

\section{Full-scale investigation}

The investigations were carried out in an aerobic-anaerobic aerated pond of a lagooning system treating effluents of a medium-size citrus processing company. The aerated lagoon depurated the citrus processing wastewater with the highest organic load (up to $20-30 \mathrm{~g} \mathrm{~L}^{-1}$ of COD) and EO concentration (over $600 \mathrm{ppm}$ ).

The lagoon (Figure 1) consisted of an earth pond with plastic waterproofing; the storage volume was $10.000 \mathrm{~m}^{3}$ and the lagoon maximum depth was $7 \mathrm{~m}$. Aeration was ensured by 1-3 floating aerators, each one with an electric power equal to $15 \mathrm{~kW}$, operating only during the night hours and the week-end. The aeration intensity was in the range 1.4$4.1 \mathrm{~W} \mathrm{~m}^{-3}$, depending on the number of floating aerators contemporarily operating. The electrical energy supply was setup to maintain a low concentration of dissolved oxygen in the wastewater surface layer (0.3$1.5 \mathrm{mg} \mathrm{L}^{-1}$ ), which maximizes the oxygen transfer efficiency to the aerobic surface layer, but avoids bad smell exhalation from the deep anaerobic layer.

Since 2006 to 2010 the values of $\mathrm{pH}$, DO and temperature of the stored wastewater were automatically surveyed each 6 hours from April to December, while the COD and EO concentrations were monthly measured; the amount of electric energy supplied and the aeration time were also evaluated.

\section{Laboratory-scale investigations}

Citrus processing wastewater was treated from July 2010 to February 2011 (first cycle, 240 days) and from December 2011 to June 2012 (second cycle, 210 days) in an experimental depuration plant, consisting of cylindrical $1-\mathrm{m}^{3}$ tanks simulating the aerobic layer of an aerobic-anaerobic lagoon (Figure 2).

In the following discussion each tank will be indicated by the symbol " $\mathrm{T}_{\mathrm{xx}, \mathrm{xx}, \mathrm{xx}}$ ", where: the first two numbers of the subscript refer to either the position of the air diffuser ("0" for positioning above the tank bottom and "1/2" for placing at mid-depth) or other information about the experimental conditions ("IN" for tank with "inoculum" wastewater and "NA" for the tank not aerated); the intermediate numbers refer to the air flow rate ("7" or " 14 " $\mathrm{L} \mathrm{m}^{-3} \mathrm{~h}^{-1}$ ); and the final two numbers refer to the aeration time (" 12 " or " 24 " hours). For example " $\mathrm{T}_{1 / 2,7,12}$ " indicates the tank with the diffuser placed at mid-depth and subject to

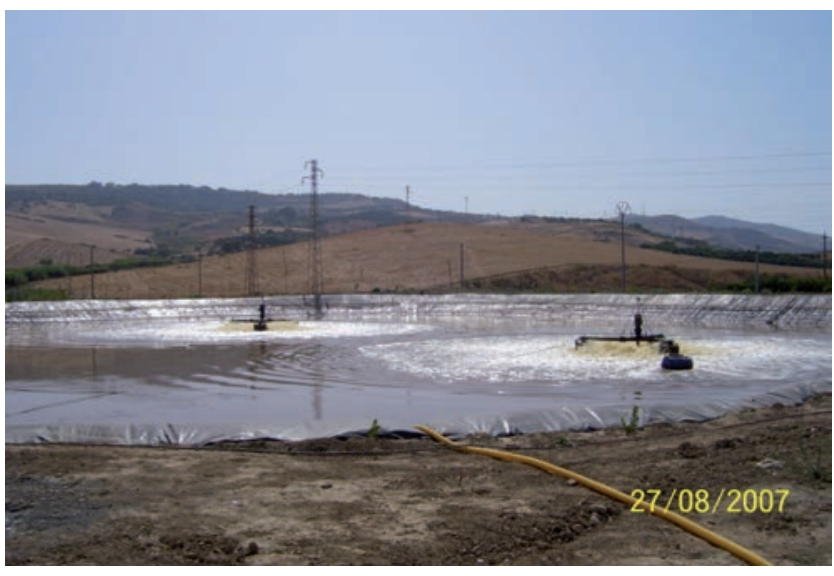

Figure 1. The full-scale aerobic-anaerobic aerated lagoon under investigation. an air flow rate of $7 \mathrm{~L} \mathrm{~m}^{-3} \mathrm{~h}^{-1}$ supplied for 12 hours per day. Finally, in the case of equal experimental conditions (for example for the tanks " $\mathrm{T}_{0,7,12}$ " a superscript has been added ("I" or "II") indicating the first ("I", 2010-2011) or second ("II", 2011-2012) depuration cycle.

All tanks, except one $\left(\mathrm{T}_{\mathrm{NA}, 0,0}\right)$ were subject to fine bubble aeration through an air diffuser fed by a blower (Table 1). The air flow rates and the power per volume unit $\left(0.6-1.2 \mathrm{~W} \mathrm{~m}^{-3}\right)$ felt among the lowest values adopted in aerated aerobic-anaerobic lagoons at full scale.

During the first depuration cycle the energy requirements under different aeration times (permanent, i.e. 24 hours per day, in the tank $\mathrm{T}_{0}$, 7,24 , or limited to the 12 night hours, in the other aerated tanks) was evaluated. After six months, the E0 concentration of wastewater in the $\operatorname{tank} \mathrm{T}_{0,7,12}$ was gradually increased up to $1400 \mathrm{ppm}$ by weekly additions of $100 \mathrm{ppm}$.

During the second cycle the intermittent aeration, which provided the highest $\mathrm{OM}$ removal rates in the previous cycle, was setup. Air flow was provided by a fine bubble diffuser fed by a blower; the diffuser was placed 5-cm above the bottom ( 0.85 -m deep below the wastewater surface, Figure $2 \mathrm{a}$ ) in all tanks, except for tank $\mathrm{T}_{1 / 2,7,12}$. In this latter the diffuser was placed at mid-depth with the lower anaerobic layer partially separated by the upper aerobic one by a wood disk, thus limiting wastewater mixing due to air bubble lift (Figure 2b).

Fifty per cent of the wastewater in one tank $\left(\mathrm{T}_{\mathrm{IN}, 7,12}\right)$ was an inoculum consisting of citrus wastewater from the previous depuration cycle and containing a spontaneous microflora already adapted to EO concentration in the range $600-1000 \mathrm{ppm}$. One tank $\left(\mathrm{T}_{\mathrm{NA}, 0,0}\right)$ was not aerated.

A preliminary characterisation of the wastewater showed an initial COD concentration close to 5-6 $\mathrm{g} \mathrm{L}^{-1}$. The ratio COD:N:P was close to 600:5:1. During the experiment, in order to restore COD consumed by microorganisms, COD was kept in the range $3-12 \mathrm{~g} \mathrm{~L}^{-1}$, adding periodically organic matter as saccharose, in order to assure food for microorganisms. Initial EO concentrations, close to $500 \mathrm{ppm}$, were always kept in the range $300-600$ ppm by adding periodically EO.

The mean values of wastewater temperature ranged from $11.3{ }^{\circ} \mathrm{C}$ (January) to $29.4{ }^{\circ} \mathrm{C}$ (August) in the first cycle and from 7.4 (February) to 29.5 (June) in the second cycle.

During the depuration cycles the COD and the EO concentrations of wastewater were evaluated every month on 0.5 -L samples of supernatant (in duplicate) using standard methods (APHA 1998; Scott and Veldhuis 1966). Dissolved Oxygen, temperature and $\mathrm{pH}$ of wastewater were measured weekly (or daily, after EO addition), $0.3 \mathrm{~m}$ under the wastewater surface, using a digital multimeter (HACH Lange HQ40).

In order to estimate the oxygen transfer to wastewater, the oxygen deficit was calculated as the difference between the saturation concentration at the measured temperature and the actual DO concentration. The ratio between the energy supplied and the measured COD removal rates was calculated to estimate energy requirement in the aerated tanks.

\section{Results and discussion}

\section{Full-scale investigation}

The initial acidity of wastewater ( $\mathrm{pH}=3.3-4$, Table 2$)$, which disturbs activated sludge processes (Tamburino et al., 2007; Bombino et al., 2009), was due to organic acid components of citrus fruits and the lactic fermentation of sugars and other carbohydrates, producing organic acids under oxygen shortage. The depuration processes acting in the aerated lagoon progressively increased the $\mathrm{pH}$ up to the final values of 4.8-8.3, Table 2), due to degradation of organic acids, and reduced the E0 concentrations (on the average by $88 \%$, Table 2). E0 
concentration generally higher than $600 \mathrm{ppm}$ (with peaks of $1000 \mathrm{ppm}$ ) never slowed down depuration processes; conversely, in activated sludge plants biological instability has been described when EO concentrations are higher than $50 \mathrm{ppm}$, due to their antimicrobial activity (Lane, 1983; Ratcliff, 1990; Kimball, 1999). No bad smell exhalations (typical of anaerobic processes) were detected in proximity of the lagoon thanks to the aeration of the surface layer.

The investigation showed a good depuration capacity of the organic load with a COD removal efficiency from 59\% (in 2010) to $97 \%$ (in 2006); the COD removal rates varied from 0.59 (in 2010) to 2.50 (in 2007) $\mathrm{g} \mathrm{L}^{-1}$ month $^{-1}$, with a high variability due to:

- the effects (contrasting each others) of COD settling and releasing from sludge in the lagoon bottom;
- the incidence of anaerobic processes in the lagoon bottom with respect to aerobic degradation in the surface layer;

- the variation in aeration times and intensity, this latter depending from the number of floating aerators contemporarily activated.

An adequate capacity of equalization in stored wastewater, which limited the variability of physico-chemical characteristics (thanks to the high retention time and volume of the lagoon), was detected.

Depuration performance did not suffer from the high EO concentrations, the high ratio COD:N:P and the very low values of wastewater $\mathrm{pH}$ (Table 2).

An analysis of the depuration input factors showed a significant reduction of:

Table 1. Experimental characteristics of the tanks utilised for depurating citrus processing wastewater at laboratory scale.

\begin{tabular}{|c|c|c|c|c|c|}
\hline Tank & $\begin{array}{c}\text { Air flow rate } \\
\left(\mathrm{L} \mathrm{m}^{-3} \mathrm{~h}^{-1}\right)\end{array}$ & $\begin{array}{l}\text { Aeration time } \\
\text { (h) }\end{array}$ & $\begin{array}{c}\text { Specific power } \\
\left(\mathrm{W} \mathrm{m}^{-3}\right)\end{array}$ & $\begin{array}{l}\text { Air diffuser } \\
\text { position }\end{array}$ & Other experimental conditions \\
\hline \multicolumn{6}{|l|}{ I cycle (July 2010 - February 2011) } \\
\hline $\mathrm{T}_{0,14,12}$ & 14 & 12 & 1.2 & Bottom & \\
\hline $\mathrm{T}_{0,7,24}$ & 7 & 24 & 0.6 & & \\
\hline $\mathrm{T}_{0,7,12}^{\mathrm{l}}$ & 7 & 12 & 0.6 & & \\
\hline \multicolumn{6}{|l|}{ II cycle (December 2011 - June 2012) } \\
\hline $\mathrm{T}^{\mathrm{II}} \mathrm{l}, 7,12$ & 7 & 12 & 0.6 & Bottom & \\
\hline $\mathrm{T}_{\mathrm{IN}, 7,12}$ & 7 & 12 & 0.6 & & Inoculum with citrus wastewater from a previous treatment cycle \\
\hline $\mathrm{T}_{1 / 2,7,12}$ & 7 & 12 & 0.6 & Mid-depth & Separation of upper (aerobic) and lower (anaerobic) layer \\
\hline $\mathrm{T}_{\mathrm{NA}, 0,0}$ & - & - & - & - & Not aerated \\
\hline
\end{tabular}

Table 2. Initial (April) and final (December) values of the main qualitative characteristics of citrus processing wastewater treated in the full-scale aerated lagoon.

\begin{tabular}{|c|c|c|c|c|c|c|c|c|c|c|}
\hline \multirow[t]{3}{*}{ Parameter } & \multicolumn{10}{|c|}{ Year } \\
\hline & \multicolumn{2}{|c|}{2006} & \multicolumn{2}{|c|}{2007} & \multicolumn{2}{|c|}{2008} & \multicolumn{2}{|c|}{2009} & \multicolumn{2}{|c|}{2010} \\
\hline & Apr & Dec & Apr & Dec & Apr & Dec & Apr & Dec & Apr & Dec \\
\hline COD concentration ( $\left.\mathrm{g} \mathrm{L}^{-1}\right)$ & 18.2 & 0.3 & 27.2 & 7.2 & 17.4 & 9.7 & 12.2 & 6.7 & 14.8 & 10.1 \\
\hline $\mathrm{pH}$ & 4.0 & 8.3 & 3.5 & 6.8 & 3.6 & 4.8 & 3.4 & 5.4 & 3.3 & 6.6 \\
\hline EO concentration (ppm) & 620 & 70 & 1030 & 40 & 810 & 50 & 380 & 17 & 440 & 120 \\
\hline
\end{tabular}

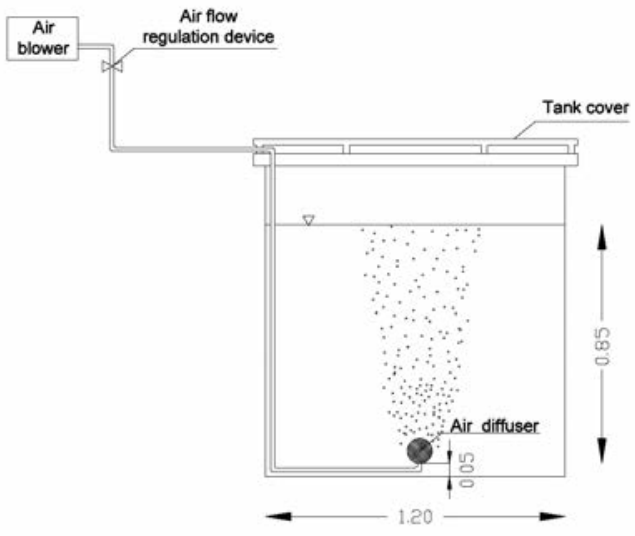

(a)

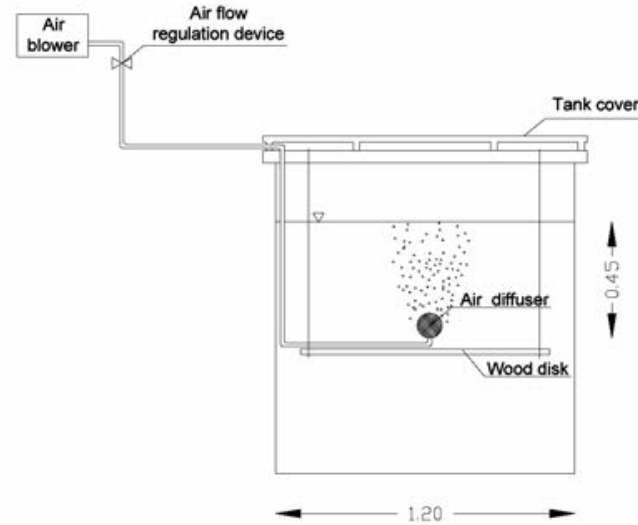

(b)
Figure 2. Scheme of the $1-\mathrm{m}^{3}$ in tanks simulating aerated lagoons (measures in metres). 
personnel requirement (lower by 75\% compared to a common activated sludge plant);

- frequency of water quality analysis (about a control per month against the daily sampling of activated sludge plants) thanks to the low wastewater qualitative variability.

Furthermore, the depuration process do not need lime (due to the natural stabilisation of $\mathrm{pH}$ in stored wastewater) and nutrient addition (thanks to the release of nitrogen and phosphorous from activated sludge on the lagoon deep bottom).

The most relevant results were related to the energy aspects. The monthly electrical energy supply per unit of removed COD was in the range 0.21 (in 2008) to 0.59 (in 2006) $\mathrm{kWh} \mathrm{kg}^{-1}$ CoD (Table 3) with an average value of $0.45 \mathrm{kWh} \mathrm{kg}^{-1}$ coD. The cost savings are mostly appreciable, because aerators worked only in the night and during the weekend (in which the energy price is lower).

The reduction of the energy requirements in the aerated lagoon under investigation can be related to:

- the significant incidence of anaerobic processes in the high-depth wastewater layer, in which the organic matter is degraded without energy requirements (Zema et al., 2012);

the higher efficiency of oxygen transfer, due to the high D0 oxygen deficit (98-99\% of saturation) thanks to the low D0 concentrations in wastewater (generally in the range $0.5-1.5 \mathrm{mg} \mathrm{L}^{-1}$ with few exceptions) induced by the low aeration intensity (Zema et al., 2012). Conversely, in the activated sludge plants DO concentrations over 2-3 mg L-1, Masotti, 2002; Tchobanoglous et al., 2006) are usual in order to assure oxygen penetration in sludge large flocs with consequent higher energy requirements.

\section{Laboratory-scale investigations}

During the investigation in the aerated tanks the $\mathrm{pH}$ increased from 4.2-5.5 up to values close to 6.3-8.0, due to degradation of organic acids in oxidation processes. The evolution of $\mathrm{pH}$ was similar among the investigated tanks (with mean differences under 5\%) and seemed to be independent on air supply. When the organic matter was added, a pH reduction was always detected, presumably due to the lactic fermentation of sugars. The lowest $\mathrm{pH}$ increase was recorded in the tank $\mathrm{T}_{\mathrm{NA}, 0,0}$ (from 5.5 to 5.7 ), due to less intense oxidation processes in the absence of aeration.

In the aerated tanks the low D0 concentrations, due to the limited air flow rates, determined a high oxygen deficit (close to $95-99 \%$ of the saturation concentration). This DO deficit induced a very high efficiency of oxygen transfer to the stored wastewater, which can be estimated as over $20 \%$ more compared to a standard activated sludge plant, in which values of oxygen deficit around $80 \%$ are usual. Furthermore, the low D0 concentration highlighted that in the aerated tanks the oxygen supplied was fully and quickly utilised by microorganisms, even at low temperature and high EO concentration.

The COD monthly removal rate in the aerated tanks was on the average six-fold higher compared to the anaerobic tank $\left(\mathrm{T}_{\mathrm{NA}, 0,0}, 0.36 \mathrm{~g} \mathrm{~L}^{-1}\right.$ month $\left.{ }^{-1}\right)$. The comparison of energy requirements under different aeration times (12 or 24 hours per day) showed that aeration in the 12 night hours determined an increase of $12 \%$ of the monthly removal rate of $\operatorname{COD}\left(0.76 \mathrm{~g} \mathrm{~L}^{-1}\right.$ month $\left.^{-1}, \mathrm{~T}_{0,14,12}\right)$ compared to the permanently aerated tank $\left(0.68 \mathrm{~g} \mathrm{~L}^{-1}\right.$ month $\left.{ }^{-1}, \mathrm{~T}_{0,7,24}^{\mathrm{I}}\right)$, although having the same total air supply (Figure 3 ). As a consequence the energy supply per unit of COD removed were about $10 \%$ lower $\left(0.57 \mathrm{kWh} \mathrm{kg}_{\mathrm{CoD}^{-1}}\right.$, tank $\mathrm{T}_{0,14,12}$, ver-

Table 3. COD removal and electrical energy supply in the full-scale aerated lagoon.

\begin{tabular}{|c|c|c|c|c|c|c|}
\hline Parameter & 2006 & 2007 & $\begin{array}{l}\text { Year } \\
2008\end{array}$ & 2009 & 2010 & Mean \\
\hline COD total reduction $\left(10^{3} \mathrm{~kg}\right)$ & 182 & 236 & 145 & 125 & 111 & 160 \\
\hline Total supply of electrical energy (MWh) & 107 & 79 & 30 & 45 & 47 & 62 \\
\hline Mean supply of electrical energy (MWh month-1) & 12.8 & 10.0 & 3.8 & 5.0 & 5.3 & 7.4 \\
\hline COD removal rate ( $\mathrm{g} \mathrm{L}^{-1}$ month $\left.^{-1}\right)$ & 2.24 & 2.50 & 0.64 & 0.68 & 0.59 & 1.33 \\
\hline Mean energy supply for unit of removed COD ( $\left.\mathrm{kWh} \mathrm{kg}^{-1} \mathrm{COD}\right)$ & 0.59 & 0.34 & 0.21 & 0.55 & 0.54 & 0.45 \\
\hline
\end{tabular}

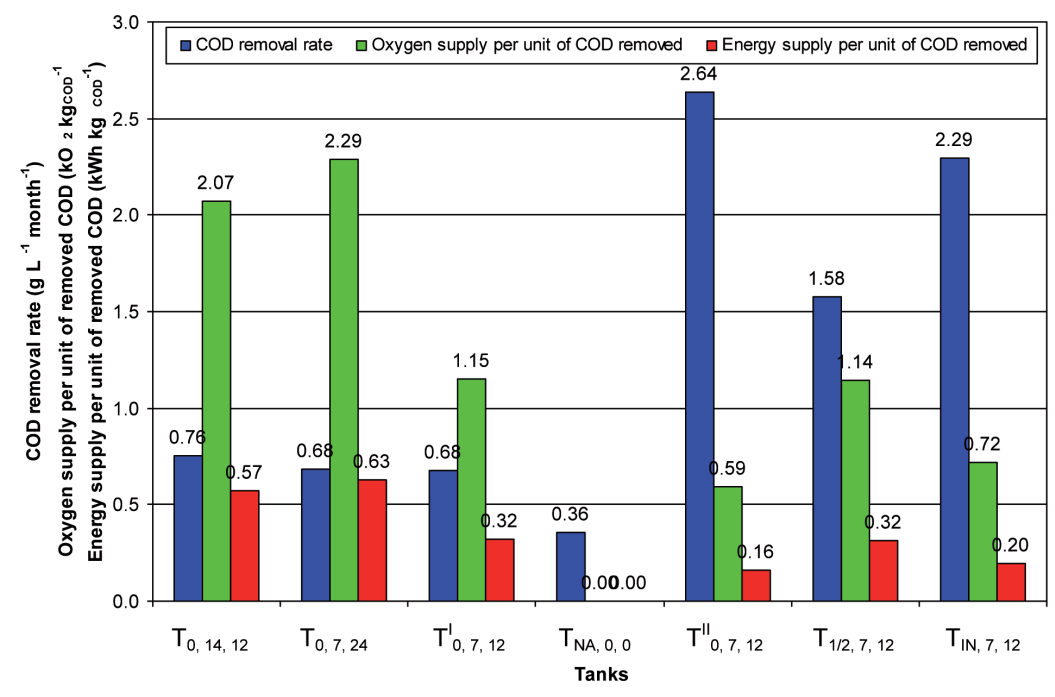

Figure 3. COD monthly removal rate as well as of oxygen and energy supply per unit of COD removed (mean and standard deviation) in the aerated tanks for depurating citrus processing wastewater at laboratory scale. 
sus $0.63 \mathrm{kWh} \mathrm{kg}_{\mathrm{COD}^{-1}}$, tank $\mathrm{T}_{0,7,24}$, Figure 3 ), which could be presumably due to the higher incidence of anaerobic processes. This result shows that limiting aeration to the 12 night hours allows a total cost saving of nearly $30 \%$, given the present price of off-peak energy in Italy, about lower by $20 \%$ than the mean daily price.

Halving the night air flow rates in the tank $\mathrm{T}_{0,7,12}^{\mathrm{I}}$ from 14 to $7 \mathrm{~L} \mathrm{~m}^{-}$ ${ }^{3} \mathrm{~h}^{-1}$ reduced by $10 \%$ the removal rate of $\operatorname{COD}\left(0.68 \mathrm{~g} \mathrm{~L}^{-1} \mathrm{month}^{-1}\right)$ compared to tank $\mathrm{T}_{0,14,12}$. Given the reduction of $50 \%$ in oxygen supply, the energy requirement per unit of COD removed $\left(0.32 \mathrm{kWh} \mathrm{kg}_{\mathrm{COD}}^{-1}\right)$ was consequently reduced by more than $40 \%$ (Figure 3 ).

These results confirm the possibility of reducing energy requirement by maximising the incidence of anaerobic processes, thanks to the reduced aeration intensity (down to $0.6 \mathrm{~W} \mathrm{~m}^{-3}$ ) and to the limitation of air supply during the 12 night hours.

The highest COD monthly removal rate $\left(2.64 \mathrm{~g} \mathrm{~L}^{-1}\right.$ month$\left.^{-1}\right)$ was measured in the tank $\mathrm{T}_{0,7,12}^{\mathrm{II}}$ (Figure 3). No positive effect of inoculum (tank $\mathrm{T}_{\mathrm{IN}, 7,12}$ ) was detected, being COD removal rate $\left(2.29 \mathrm{~g} \mathrm{~L}^{-1}\right.$ month$\left.^{-1}\right) 13 \%$ lower than in the tank $\mathrm{T}_{0,7,12}^{\mathrm{II}}$ (Figure 3).

The COD monthly removal rate detected in the tank $\mathrm{T}_{1 / 2,7,12}\left(1.58 \mathrm{~g} \mathrm{~L}^{-}\right.$ ${ }^{1}$ month $^{-1}$ ) was $40 \%$ lower than in the tank $\mathrm{T}^{\mathrm{II}}{ }_{0,7,12}$ (Figure 3 ). This may be due to the fact that part of oxygen supplied in the upper layer was not presumably transferred to the wastewater, due to the shorter contact time among air bubbles and wastewater because of the halved water depth: this confirms the influence of diffuser submergence on oxygen transfer efficiency, as reported in other studies (Casey, 2009; Popel and Wagner, 1994).

The lowest energy requirement per unit of COD removed was detected in the tank $\mathrm{T}_{0,7,12}^{\mathrm{II}}\left(0.16 \mathrm{kWh} \mathrm{kg}_{\mathrm{COD}^{-1}}\right)$. Tanks $\mathrm{T}_{\mathrm{IN}, 7,12}\left(0.2 \mathrm{kWh} \mathrm{kg}_{\mathrm{COD}^{-1}}\right)$ and $\mathrm{T}_{1 / 2,7,12}\left(0.32 \mathrm{kWh} \mathrm{kg}_{\mathrm{COD}^{-1}}{ }^{-1}\right)$ recorded values respectively by $25 \%$ and $100 \%$ higher (Figure 3), while the energy requirements in the first depuration cycle were 2 to 4 -fold, presumably because of the different composition of the citrus processing wastewater.

The comparison of the average COD removal rate recorded in the

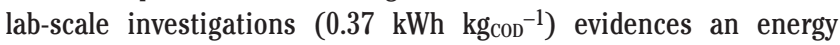
requirement of the same order of magnitude as the full-scale aerated

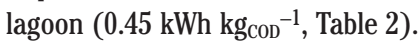

The low energy requirements detected in aerated lagoons during this investigation are not achievable in activated sludge plants treating agro-industrial wastewater (usually $2.0 \mathrm{kWh} \mathrm{kg}_{\mathrm{COD}^{-1}}$ in the smallest plants, Cheng et al., 2011). In high loading rate activated sludge processes lower energy requirements (down to $0.5 \mathrm{kWh} \mathrm{kg}_{\mathrm{COD}^{-1}}{ }^{-1}$ ) are observed only for large and well regulated plants treating urban wastewater, Masotti, 2002; Tchobanoglous et al., 2006).

The depuration processes were not influenced by the low D0 and nutrient concentrations, which instead negatively affect biomass settleability and recirculation level in the activated sludge plants, where filamentous bacteria can take advantage of large flocs of sludge, because of their higher surface/volume ratio (Martins et al., 2004; Liu and Liu, 2006). Given that sludge settleability plays a secondary role in aerated ponds, filamentous bacteria did not induce any negative impact on the overall treatment performance.

The gradual addition of E0 up to $1400 \mathrm{ppm}\left(\operatorname{tank} \mathrm{T}_{0,7,12}^{\mathrm{I}}\right)$ did not slow down the removal rate of the organic load. The increase of the EO tolerance recorded in the experimental tank may be presumably attributed to microbial adaptation to terpenes contained in E0 and/or non uniform EO concentration in the tank, due to the incomplete mixing of wastewater. The tolerance to high EO concentrations in aerated ponds is more than one order of magnitude higher than the maximum concentration of $50 \mathrm{ppm}$ tolerated by activated sludge processes (Ratcliff, 1990; Kimball, 1999).

\section{Conclusions}

This study has investigated depuration processes of citrus wastewater with high concentration of EO in aerobic-anaerobic aerated lagoons at full and laboratory scales. The outcomes of these investigations basically confirm that aerated lagoons are able to reduce the high organic load of agro-industrial wastewater with high EO concentrations at low energy costs.

The monitoring of five citrus wastewater depuration campaigns in the full-scale lagoon highlighted that biological processes, also at high E0 concentrations (600-1000 ppm) go regularly, because they do not depend on sludge settleability, contrarily to the activated sludge plants affected by biological instability when EO concentrations are higher than $50 \mathrm{ppm}$.

Lab-scale investigations indicated that:

it is possible to increase energy efficiency by limiting aeration to the 12 night hours (with a total cost saving of about $30 \%$ ) or by halving the night air flow rate to $7 \mathrm{~L} \mathrm{~h}^{-1} \mathrm{~m}^{-3}$ (with a reduction of $40 \%$ in energy requirement);

a gradual increase of EO concentration up to $1400 \mathrm{ppm}$ seems to induce a microbial adaptation which allows regular biological processes, but an inoculum of $50 \%$ of wastewater with microflora already adapted to high E0 concentration does not induce any positive effect on the removal rate of the organic load;

positioning the air diffuser $0.45-\mathrm{m}$ above the tank bottom (instead of $0.05-\mathrm{m}$ ) determines a decrease of COD removal rate, presumably due to a reduced oxygen absorption by the wastewater due to the reduced water depth.

On the whole, the results of the investigations confirm that depuration of agro-industrial wastewater in aerated lagoons is a valid alternative to the intensive biological plants (as the most common activated sludge processes), thanks to their higher reliability and lower energy requirements.

\section{References}

APHA. 1998. Standard methods for the examination of water and wastewater, XX Ed., Washington, APHA, USA.

Bombino G., Tamburino V., Zema D.A., Zimbone S.M. 2009. Depuration of citrus processing wastewater in aerated biological ponds. Proceedings of the Congress of the Italian Association of Agricultural Engineers. Ischia (Italy), 12-16 September.

Casey T.J. 2009. Diffused air aeration systems for the activated sludge process. Design performance testing. Aquavarra Research Publications - Water Engineering Papers. Available from http://www.aquavarra.ie/AerationP4.pdf. Accessed: February 2013.

Jail A., Boukhoubza F., Nejmeddine A., Duarte J.C., Sayadi S., Hassani L. 2010. Traitement des effluents d'huileries par un procédé combinant un traitement intensif (Jet_Loop Reactor) suivi d'un traitement extensif (bassins de stabilisation), Environ. Technol., 31: 533-543 (in French).

Kimball D.A. 1999. Citrus processing, 2nd Edition. Aspen Publishers, Inc. Gaithersburg, MD, USA.

Lane A.G. 1983. Removal of peel oil from citrus peel press liquors before anaerobic digestion, Environ. Technol. Lett. 4: 65-72.

Liu Y., Liu Q.-S. 2006. Causes and control of filamentous growth in aerobic granular sludge sequencing batch reactors. Biotechnology Advances 24: 115-127.

Martins A.M.P., Pagilla K., Heijne J.J., van Loosdrecht M.C.M. 2004. 
Filamentous bulking sludge - a critical review. Water Research 38 : 793-817.

Masotti L. 2002. Depurazione delle acque reflue. Il Sole 24 Ore Edagricole (Ed.), Bologna (Italy), (in Italian).

Popel H.J., Wagner M. 1994. Modelling of oxygen transfer in deep diffused-aeration tanks and comparison with full-scale data. Water Science Techn. 30(4): 71-80.

Ratcliff M.W. 1990. Citrus processing waste prevention, handling and treatment, Citrus world, Lake Wales, Florida, USA.

Scott W.C., Veldhuis M.K. 1966. Rapid estimation of recoverable oil in citrus juices by bromate titration. J. AOAC Int., 49: 628-633.

Tamburino V., Zema D.A., Zimbone S.M. 2007. Depuration processes of citrus wastewater, Proceedings of the $3^{\text {rd }}$ International Symposium of CIGR Section VI "Food and agricultural products: processing and innovations". Naples (Italy), 24-26 September.

Tchobanoglous G., Burton F.L., Burton F., Stensel H.D. 2002. Wastewater engineering. Treatment and reuse, Inc Metcalf \& Eddy, McGraw-Hill Company, New York, USA.

Van Dyke S., Jones S., Ong S.K. 2003. Cold weather nitrogen removal deficiencies of aerated lagoons, Environ. Technol. 24: 767-777.

Zema D.A., Andiloro S., Bombino G., Tamburino V., Sidari R., Caridi A. 2012. Performance of aerated ponds in depurating citrus processing wastewater with high concentrations of essential oils. Environmental Technology 33 (11): 1255-1260. 